\title{
Scientific and methodical approaches to determining the center- orientation of financial conglomerates with the factor and cluster analysis
}

\section{Tetyana Vasilyeva}

Dr. Professor, Director of the Research Institute of Finance, Economics and Management named by Oleg Balatskiy, Sumy State University, Head of ARMG Publishing, Ukraine

\section{Vadim Kozyriev}

Ph.D., Asistant of Economic Cybernetics Department, Sumy State University, Ukraine

(C) The Authors, 2017. This article is published with open access at ARMG Publishing.

\begin{abstract}
Involving Ukraine in the globalization of the world economic and financial system makes the transfer of most of the positive and negative effects of the external world in Ukrainian conditions that will have consequences for the development of the domestic financial sector. It is important to note that the presence of foreign capital affects the stability of the banking system and the efficiency of its operations.

The process of entry of foreign banks on the domestic market of banking services is controversial. It is associated with the activation of financial conglomerates types of "bancassurance" and "allfinanz", aimed at expanding its own branch network that stay in a constant search of new markets. In addition, the powerful financial conglomerates have their own competitive advantages and significant financial resources.
\end{abstract}

Keywords: globalization, financial conglomerates, bancassurance, allfinanz, instability.

JEL Classification: C100, C440

\section{Introduction}

The positive effects of the entry of foreign financial conglomerates in the domestic financial market are advisable to select:

$>$ introduction of modern banking technology that improves the quality of customer service;

$>$ data reduce the cost of standardized banking products on the one hand, leads to a reduction of profitability of local banks by reducing the interest margin, but on the other - increases the efficiency of the banking system as a whole;

$>$ using high standards of banking risk management;

$>$ improving the investment climate, primarily due to the greater availability of credit products from foreign banks and the growing confidence of foreign investors in the national economy, which is one of the important factors stabilize the domestic financial market and economic recovery of the state.

At the same time, the expansion of bank foreign capital to the domestic financial market in parallel with the positive effects carries a number of risks, implementation of which could lead not only to structural changes in the banking sector, but also cause uncontrollable consequences for the national economy as a whole:

$>$ entry of financial conglomerates may lead to decrease in equal return of Ukrainian banks; and they will not withstand under competition pressure, wich will lead to a state of bankruptcy, that would deep the financial instability in Ukraine;

$>$ the displacement of domestic banks from profitable segments of the banking market (the market of consumer lending and large corporate clients);

$>$ foreign banks try to establish control over economically efficient sectors of the national economy, and therefore - imposition model's dependent development by the national economy, may lead to the loss financial and economic independence of Ukraine and its economic security. 
The structural backwardness and institutional weakness of the domestic economy increases the likelihood of strain development, because at the present stage the aims of foreign banks do not coincide with the economic and social priorities of Ukraine:

$>$ amplification of dollarization of the domestic economy, the threat of undermining the stability of the national currency;

$>$ the likelihood of a sharp outflow of foreign capital in the event of changes in the economic situation in Ukraine or in the countries of origin of the capital.

Financial conglomerates with foreign capital are represented at the insurance market. Generally, non-residents interested in domestic insurance companies are in the financial center of the country, with an extensive branch network and well-established sales channels. Such companies, they believe, can provide the necessary return activities.

After a detailed analysis of domestic and foreign conglomerates that operate in Ukraine, authors concluded that their composition is heterogeneous and presented in three sectors of the financial market: banking, insurance and investment (Table 1).

Table 1. Configurations of conglomerates in the financial market of Ukraine

\begin{tabular}{|c|c|c|c|c|}
\hline & Financial conglomerate & Bank & Insurance company & Investment fund \\
\hline 1. & Group "Privat" & Privatbank & - & NPF Private Fund \\
\hline 2. & Prominvest & Prominvestbank & Veksel & Prestige Prominvest \\
\hline 3. & Alfa Ukraine & Alfa-Bank & Alfa Insurance & Ltd. AMC "Alpha Capital Management" \\
\hline 4. & Delta Bank & The "Delta" & SC "Delta Life" & Ltd. AMC "Delta Capital" \\
\hline 5. & Credit-Dnepr & Bank "Credit-Dnepr" & - & AMC Ltd. "Credit Dnepr-Invest" \\
\hline 6. & Renaissance (FUIB) & The "Renaissance Capital" & Renaissance, Renaissance Life & - \\
\hline 7. & Arcade & Bank "Arcade" & IC "Arcade-guarantor" & - \\
\hline 8. & Diamond & Diamond Bank & - & AMC Ltd. "Diamond Investment Management" \\
\hline 9. & RZB-UNIQA & The "Raiffeisen Bank Aval" & UNIQA Life (UNIQA Life) & - \\
\hline 10. & BNP Paribas & Ukrsotsbank & "Oranta" & ONPF "UkrsotsFond" \\
\hline 11. & ING & ING Bank Ukraine & INGO UKRAINE life & - \\
\hline 12. & Intesa Sanpaolo SPA & Praveksbank & - & - \\
\hline 13. & Citigroup & Citibank & - & - \\
\hline 14. & SEB & SEB bank & SEB Life Ukraine & - \\
\hline 15. & Credit Agricole & Credit Agricole & - & - \\
\hline 16. & Societe Generale & Icarus (ProFinBank SITEMAP) & - & - \\
\hline 17. & Allianz & - & ALLIANZ UKRAINE & - \\
\hline 18. & Allianz & - & Allianz Life & - \\
\hline 19. & AIG & - & Alico UKRAINE & - \\
\hline 20. & AXA & - & AXA Ukraine & - \\
\hline 21. & GRAWE & - & Grave UKRAINE & - \\
\hline 22. & GRAWE & - & Generali Garant & - \\
\hline 23. & Generali & - & Generali life insurance & - \\
\hline 24. & Cardiff & - & BNP Paribas & - \\
\hline 25. & Peter Keller & - & Home Credit Insurance & - \\
\hline
\end{tabular}

So, we can say that the financial conglomerates in Ukraine are the most common types: bank-oriented (bancassurance), insurance-oriented (assurefinance), and "equal" (allfinanz).

The financial statements of 25 financial conglomerates that are presented in the domestic financial market, received from the official website of financial conglomerates, National Bank of Ukraine and the website "Forinshurer" serve as initial data for further calculations. Empirically it was found that the financial performance of individual members of the integrated financial intermediary may act as internal factors of instability affecting the conglomerate. Each member of the financial conglomerate is chosen from the system of absolute and relative performance.

The following indicators were selected for banks:

$>$ total assets;

$>$ the total amount of obligations;

$>$ the total amount of liabilities; 
$>$ equity;

$>$ financial results;

$>$ return on assets;

$>$ return on equity;

$>$ multiplicator of capital;

$>$ correlation between capital and liabilities;

$>$ coefficient for capital adequacy;

$>$ coefficient for active involvement lent and borrowed funds;

$>$ financial leverage.

The following indicators were selected for insurance companies:

$>$ total assets;

$>$ equity;

$>$ the total amount of obligations;

$>$ gross premiums;

$>$ gross payments;

$>$ insurance reserves;

$>$ ratio of total debt;

$>$ current ratio;

$>$ adequacy ratio of reserves;

$>$ rate of business activity;

$>$ factor of the debt burden;

$>$ loss ratio.

As for members of the investment market, the analysis is complicated by the limited statistics and diversity of participants. Note that in times of crisis, most companies stopped their activities, came from the financial conglomerate and others. To describe this situation, authors have chosen the binary method. Since " 1 " means that the period had a financial conglomerate composed of representatives of the investment market, and the number "0" - that did not.

The law of Ukraine has no fixed definition of "financial conglomerate" and it is difficult to discover which type is a single-integrated financial intermediary. To determine which factors of instability affecting every single type of financial structure, it is necessary to determine the orientation. Purely, foreign financial conglomerates are largely represented in the insurance market, and are also well-known as insurance-oriented. The remaining financial conglomerates require additional research. Cluster analysis was chosen from the available mathematical tools.

Cluster analysis of the impact of domestic factors (basic characteristics of the financial conglomerates) to center-integrated financial intermediaries was carried out through the use of techniques such as clustering method parameters $k$ of medium and method for simultaneous clustering variables (column) and observations (rows). The implementation of this phase of scientific and methodical approach will allow to group the internal factors on homogeneous in their characteristics and the peculiarities of using clusters with further study of the impact of identified groups of indicators on orientation of financial conglomerate. The implementation of cluster analysis is possible in the packet of analysis in program Statistics. By means of a though analysis, it is possible to perform:

1. Report forming from analyzed data to a single table.

2. Normalization of indicators.

3. Calculation of Euclidean distances between clusters (the foundation for clustering)

\begin{tabular}{|l|c|c|}
\hline \multirow{2}{*}{$\begin{array}{c}\text { Number } \\
\text { of } \\
\text { cluster }\end{array}$} & \multicolumn{2}{|c|}{$\begin{array}{c}\text { Euclidean distance between clusters of bank-oriented and } \\
\text { insurance-oriented financial conglomerates }\end{array}$} \\
\cline { 2 - 3 } & Ho. 1 & Ho. 2 \\
\hline Ho. 1 & 0,000000 & 1,176556 \\
\hline Ho. 2 & 1,084692 & 0,000000 \\
\hline
\end{tabular}

Figure 1. Euclidean distance between clusters of bank-oriented and insurance-oriented financial conglomerates 
Analysis of the figure shows that the smaller value of Euclidean distance is the closer value of considered parameter corresponding to the center of the cluster. In turn, the concentrated value to each other impacts on center-orientation of financial conglomerate form corresponding cluster.

4. Definition of descriptive statistics for each selected clusters (performance characteristics of selected homogeneous groups) Figure 2 (bank-oriented financial conglomerates) and in Figure 3 (according to insurance-oriented financial conglomerates):

\begin{tabular}{|c|c|c|c|}
\hline \multirow[b]{2}{*}{ перемен. } & \multicolumn{3}{|c|}{$\begin{array}{l}\text { Описат.статистики для кластера } 1 \text { (Вихідні данні) } \\
\text { Кластер содержит } 7 \text { набл. }\end{array}$} \\
\hline & Среднее & $\begin{array}{l}\text { Стандарт } \\
\text { отклон. }\end{array}$ & Дисперс. \\
\hline Var1 & 0,171000 & 0,349855 & 0,122398 \\
\hline Var2 & 0,282351 & 0,961378 & 0,924248 \\
\hline Var3 & 0,195346 & 0,303645 & 0,092200 \\
\hline Var4 & 0,193767 & 0,599341 & 0,359210 \\
\hline Var5 & $-0,455256$ & 1,378897 & 1,901358 \\
\hline Var6 & $-0,372982$ & 1,425205 & 2,031210 \\
\hline Var7 & $-0,273585$ & 1,129354 & 1,275440 \\
\hline Var8 & 0,374391 & 1,420580 & 2,018047 \\
\hline Var9 & $-0,043174$ & 1,102875 & 1,216334 \\
\hline Var10 & $-0,270556$ & 0,143196 & 0,020505 \\
\hline Var11 & 0,450515 & 0,733379 & 0,537845 \\
\hline Var12 & 0,171881 & 1,279834 & 1,637975 \\
\hline Var13 & 0.179474 & 1.078869 & 1.163959 \\
\hline
\end{tabular}

Figure 2. Descriptive statistics of the first cluster of the bank-oriented financial conglomerates

\begin{tabular}{|c|c|c|c|}
\hline \multirow[b]{2}{*}{ перемен. } & \multicolumn{3}{|c|}{$\begin{array}{l}\text { Описат.статистики для кластера } 2 \text { (Вихідні данні) } \\
\text { Кластер содержит } 2 \text { набл. }\end{array}$} \\
\hline & Среднее & $\begin{array}{l}\text { Стандарт } \\
\text { откпон. }\end{array}$ & Дисперс. \\
\hline Var1 & $-0,63288$ & 0,008121 & 0,000066 \\
\hline Var2 & $-0,46551$ & 0,378427 & 0,143207 \\
\hline Var3 & $-0,60608$ & 0,047119 & 0,002220 \\
\hline Var4 & $-0,20137$ & 0,571665 & 0,326801 \\
\hline Var5 & 0,20171 & 0,038673 & 0,001496 \\
\hline Var6 & 0,09366 & 0,175359 & 0,030751 \\
\hline Var7 & 0,15637 & 0,203635 & 0,041467 \\
\hline Var8 & $-0,48628$ & 0,330175 & 0,109016 \\
\hline Var9 & $-0,68389$ & 0,472477 & 0,223234 \\
\hline Var10 & 1,49913 & 2,725869 & 7,430363 \\
\hline Var11 & $-1,57524$ & 1,392809 & 1,939916 \\
\hline Var12 & 0,40786 & 1,735740 & 3,012793 \\
\hline Var13 & -0.62816 & 0.040068 & 0.001605 \\
\hline
\end{tabular}

Figure 3. Descriptive statistics of the second cluster of insurance-oriented financial conglomerates

5. Identification of components from selected clusters and calculate the distance from the center of each cluster to the relevant factors.

\begin{tabular}{|c|c|c|c|c|c|}
\hline & \multicolumn{5}{|c|}{$\begin{array}{l}\text { Элементы кластера номер } 1 \text { (Вихідні данні) } \\
\text { и расстояния до центра кластера. } \\
\text { Кластер содержит } 7 \text { набл. }\end{array}$} \\
\hline & $\begin{array}{c}\text { Набл.Но. } \\
\text { С_2 }\end{array}$ & $\begin{array}{c}\text { Набл.Но. } \\
\text { С_3 }\end{array}$ & $\begin{array}{c}\text { Набл.Но. } \\
\text { С_4 }\end{array}$ & $\begin{array}{c}\text { Набл.Но. } \\
\text { С_6 }\end{array}$ & $\begin{array}{c}\text { Набл.Но. } \\
\text { С_9 }\end{array}$ \\
\hline Расcт. & 0,683576 & 0,410618 & 1,120984 & 1,021856 & 0,728564 \\
\hline
\end{tabular}

Figure 4. Components of the first cluster of the bank-oriented financial conglomerates

\begin{tabular}{|l|l|l|}
\hline & \multicolumn{2}{|l|}{ Элементы кластера номер 2 (Вихідні данні) } \\
& и расстояния до центра кластера. \\
& Кластер содержит 2 набл. \\
\cline { 2 - 3 } & Набл.Но. & Набл.Но. \\
С_7 & С_14 \\
\hline Расст. & 0,601309 & 0,601309 \\
\hline
\end{tabular}

Figure 5. Components of the first cluster of insurance-oriented financial conglomerates

Cluster analysis conducted to determine which type of financial conglomerates analyzed includes integrated education. So C_2 is responsible for the financial conglomerate "Prominvest", C_3 responsible for "AlfaUkraine" C_4 responsible for the "Delta Bank", C_6 charge for "Renaissance" (PUMB) and C_9 responsible for "RZB-UNIQA". This group belongs to bank-oriented financial conglomerates, the core of which is the 
banking institution. Financial conglomerates as "Arcade" (C_7) and "SEB" (C_14) represent a group insurance-oriented financial conglomerates.

Cluster analysis immediately rejected a number of financial conglomerates refered to bank-oriented. This is because part of the integrated education includes both bank and a representative of the investment market. Such financial conglomerates tend to relate it to "bank-oriented" type. Typical representatives of foreign financial conglomerates, received their representation in the domestic insurance market is also not taken into account. These financial conglomerates are well-known as insurance-oriented and presented by insurance company. This list includes: "Allianz", “AIG”, “AXA", "GRAWE”, "Generali”, "Peter Keller” and "Cardiff”.

At this division it should be noted that it is not perfect. First, this is due to the inclusion of the financial conglomerate "RZB-UNIQA" to the bank-oriented part of financial conglomerates. Foreign practice states that the financial conglomerate should treat to the insurance-oriented financial conglomerates in accordance with Directive 2002/87/EC of the European Parliament and Council, Article 3 "Thresholds for identifying a financial conglomerate". In our opinion, such an error in the distribution of clusters is associated with the specifics of the financial conglomerate above the financial market of Ukraine with its pronounced as bankoriented. Secondly, the financial conglomerate "BNP Paribas" was included into the bank-oriented financial conglomerates. On the one hand, this division is logical because "BNP Paribas" of "Société Générale" and "Crédit Agricole" is the "big three" of the French banking market. On the other hand, the financial conglomerate gradually change their development vectors and begins to develop other sectors of the financial market, insurance and investment. According to many experts, the dynamic development of the insurance company BNP Paribas Cardif contributes to significant changes in the financial conglomerate, leading to the emergence of new threats and opportunities.

6. The next phase involves analysis charting components of selected clusters in terms of observations to display the dynamic changes visually (Figure 6).

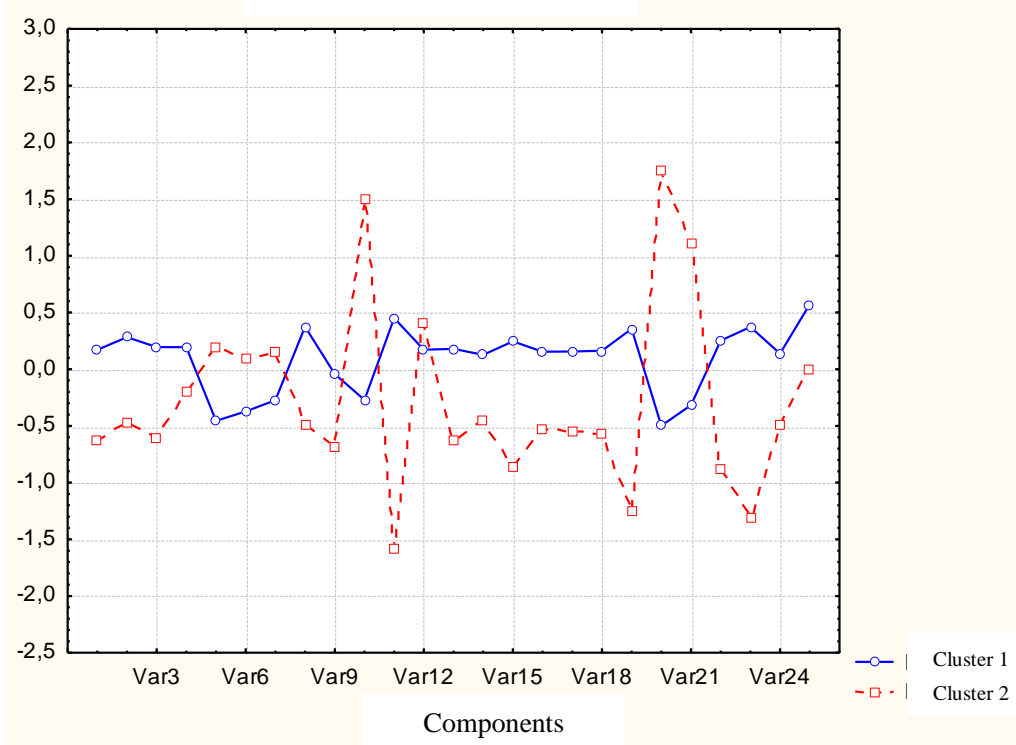

Figure 6. Graph components of selected clusters of internal factors influencing the distribution between bank-oriented and insurance-oriented financial conglomerates

In this case, the schedule means for each cluster reflects the influence of certain internal factors of instability in the financial conglomerate. The horizontal axis corresponds to the calculated value performance of financial conglomerates, which would be the factors of internal instability (Var 1 - Var 25). The vertical axis corresponds to the strength of the effect of individual indicators of the financial conglomerate in deviation from the conventional level of homogeneity.

So, the first cluster of bank-oriented financial conglomerates is within the range of -0.5 to 0.5 . This means that most of the analyzed factors are uniform and equally affects the allocation of the financial conglomerate to the group "bank-oriented". However, there are factors which caused the rejection of the final distribution. For "bank-oriented" financial conglomerates are those factors: Var 5 (financial results of the bank), Var 8 
(multiplier of capital) Var 10 (sufficiency of equity), Var 11 (coefficient of activity attracting borrowed funds) and Var 25 (presence of a representative of the financial market).

Such instability follows upon the entrance to the group of insurance-oriented financial conglomerates influenced by factors: Var 9 (the ratio of equity to total liabilities), Var 10 (capital adequacy), Var 11 (coefficient of activity attracting borrowed funds), Var 12 (financial leverage), Var 19 (ratio of total debt), Var 20 (current ratio), Var 21 (insurance reserves adequacy ratio) and Var 23 (debt load factor).

Determining an orientation of financial conglomerate allows us to organize the results and identify what indicators deepened internal instability of each group of financial conglomerates. This approach allows to assess the impact and the strength of each of analyzed factors, using the method of structural analysis.

During crisis there is a need to establish the main factors of instability that triggered its occurrence and spread on the financial markets. Expanding cooperation between financial institutions and the emergence of integrated financial intermediaries not only define the main directions of further development of the financial market but also identify the impact of structural relationships between all participants. In terms of conglomerate, a newly created association as a single system can be considered a combination of various members of the financial market can be considered.

Thus an adequate model of structural analysis in relationships between components of the financial conglomerate in determination of deviations which performance the integrated provoking mediator spreading of financial instability is developed.

The effective tools in identifying relationships between elements of a complex system that allows you not only to quantify and formalize causal dependence of economic indicators on the basis of regression analysis, but also to realize the factor analysis and examine the adequacy of the constructed model of structural analysis and test the statistical significance of the parameters in modeling structural equations. It is proposed to implement causal modeling-based software system Statistics. The information base simulation exercising causal relationships among financial conglomerate are the financial indicators (and reject) in the context of the insurance sector, banking and investment sector for the period from 2008 to 2014.

The formalization model of structural analysis in relationships between components of macroeconomics involves the implementation of this sequence of stages:

1. Detecting the priority factors of instability using the method of principal components.

2. Detecting the multivariate regression between endogenous and exogenous variables model (on which structural equation were constructed) and make their economic interpretation.

3. Evaluation of relevant factors influencing the volatility and construction of conglomerate matrix-reflectors; check the adequacy of constructed model based on indexes uncentrality and compliance with covariance matrices of initial data and converted as a result of structural analysis.

4. Analysis of the stability of structural analysis model based on the characteristics of the elements of the matrix-reflector.

It is proposed to prioritize the elements of performance evaluation system by principal components of FC (financial conglomerate) and conduct their structural analysis. As the input data 12 indicators of the bank (BANK1 - BANK12) and 12 of the financial performance of insurance companies (INS1 - INS12) members of the 25 conglomerates represented in the domestic financial market were selected. The presence-absence of representatives of the investment sector (INV) as a part of a financial conglomerate affects binary variables (1 or 0$)$.

Implementation of these steps on the example of a financial conglomerate of the group "Privat":

Stage 1. Prioritization and performance evaluation of the elements of conglomerates. Thus, the group "Privat", which includes a bank and investment companies only, it is necessary to determine the degree of importance of selected characteristics of banking performance component. As this phase it is offered to apply the method of principal components, the practical implementation is realized in a package Statistics (Figure 7). 


\begin{tabular}{|l|c|c|c|c|}
\hline \multirow{2}{*}{ Variable } & \multicolumn{4}{|c|}{ Factor coordinates of the variables, based on correlations (Spreadsheet1.sta) } \\
\cline { 2 - 5 } & Factor 1 & Factor 2 & Factor 3 & Factor 4 \\
\hline BANK1 & $-0,760609$ & $-0,633917$ & $-0,137999$ & 0,019160 \\
\hline BANK2 & $-0,775566$ & $-0,615712$ & $-0,136560$ & 0,016919 \\
\hline BANK3 & $-0,759799$ & $-0,635273$ & $-0,136188$ & 0,019350 \\
\hline BANK4 & $-0,596665$ & $-0,789642$ & $-0,128741$ & 0,040351 \\
\hline BANK5 & $-0,338361$ & 0,688266 & $-0,639887$ & $-0,047757$ \\
\hline BANK6 & 0,157517 & 0,980908 & $-0,092652$ & 0,066199 \\
\hline BANK7 & 0,301015 & 0,940080 & $-0,151175$ & 0,051701 \\
\hline BANK8 & $-0,861220$ & 0,495485 & 0,105565 & $-0,002564$ \\
\hline BANK9 & 0,858612 & $-0,492631$ & $-0,139051$ & 0,007756 \\
\hline BANK10 & 0,857942 & $-0,492392$ & $-0,142215$ & 0,008354 \\
\hline BANK11 & $-0,858612$ & 0,492631 & 0,139051 & $-0,007756$ \\
\hline BANK12 & $-0,863862$ & 0,489664 & 0,110978 & $-0,001886$ \\
\hline
\end{tabular}

Figure 7. Results of prioritizing performance assessment as a part of the banking group "Privat"

Based on Figure 7 (the closer the value of factorial coordinates, taken in magnitude to the unit value, the more important figure in question), we can conclude the following sequence includes a performance evaluation component of the banking group "Privat":

1) BANK 12 - financial leverage;

2) BANK 8 - equity multiplier (EM);

3) BANK 9 - the ratio of equity to total liabilities.

Thus, based on a detailed analysis of the results of the method of principal components' a summarizing the most influential factors considered the elements of conglomerate was held (Table 2).

Table 2. Results of systematizing the priority items in performance evaluation of financial conglomerates

\begin{tabular}{|c|c|c|c|c|c|c|c|c|c|c|c|c|c|c|c|c|c|c|c|c|c|c|c|c|c|c|}
\hline \multirow{2}{*}{ 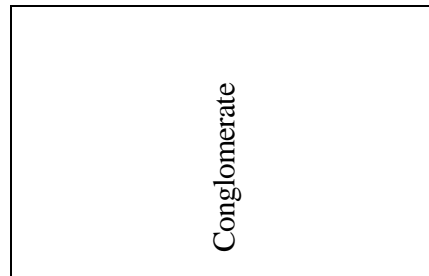 } & \multicolumn{12}{|c|}{ Bank (BANK) } & \multicolumn{12}{|c|}{ Insurance company (INS) } & \multicolumn{2}{|c|}{\begin{tabular}{|c}
$\begin{array}{c}\text { Investment market } \\
\text { (INV) }\end{array}$ \\
\end{tabular}} \\
\hline & 党 & 党 & 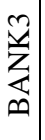 & 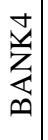 & 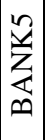 & 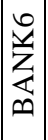 & $\underset{n}{z}$ & 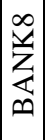 & 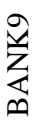 & 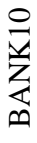 & 离 & $\frac{N}{Z}$ & $\overline{\widetilde{n}}$ & $\tilde{z}$ & $\tilde{z}$ & & & & & $\underline{\Sigma}$ & $\begin{array}{l}\infty \\
\tilde{n} \\
\text { Z }\end{array}$ & 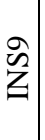 & $\begin{array}{l}0 \\
\bar{n} \\
\underline{Z} \\
\underline{Z}\end{array}$ & $\begin{array}{l}= \\
\bar{n} \\
Z \\
Z\end{array}$ & $\frac{\stackrel{\sim}{n}}{\check{Z}}$ & 文 \\
\hline Private* & & & & & & & & 2 & 3 & & & 1 & - & - & - & - & & - & - & - & - & - & - & - & - & \\
\hline Prominvest* & 2 & 1 & 3 & & & & & 4 & & & & & & & 2 & & & & & 1 & & & & & & \\
\hline Alfa Ukraine* & 1 & 2 & 3 & & & & & & & & & & & 4 & & 3 & & & & & & 1 & 2 & & & \\
\hline Delta Bank* & & 1 & 2 & & & & & & & & & 3 & & 1 & & & & & & & 2 & & & & & \\
\hline Credit-Dnepr* & & & 5 & & 2 & & 1 & & 3 & 4 & & 6 & - & - & - & - & & 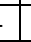 & - & - & - & - & - & - & - & \\
\hline Renaissance (PUMB)* & 3 & & & & & & & & & 1 & 2 & & & & & & & 1 & & 3 & & & & & 2 & - \\
\hline Arcade** & 4 & & & & 3 & 1 & 2 & & & & & & 1 & 2 & & & & & & & & & 3 & & & \\
\hline Diamond* & 2 & 1 & 3 & & & & & 5 & 6 & & & 4 & - & - & - & - & & - & - & - & - & - & - & - & - & \\
\hline RZB-UNIQA** & 1 & 3 & & & & & & 2 & & & & & & 2 & & 3 & & & 1 & & & & & & & - \\
\hline BNP Paribas** & & & & 2 & & & & 1 & & & & 3 & & & & 2 & & 1 & 3 & & & & & & & \\
\hline ING* & & & 2 & 1 & & & & 4 & 3 & & & & 1 & & 3 & & & & & 2 & & & & & & - \\
\hline SEB ** & 1 & 3 & & & & & & 4 & & & & 2 & & & 1 & & & & 3 & 2 & & & & & & - \\
\hline Number of instances, including & 7 & 6 & 6 & 2 & 2 & 1 & 2 & 7 & 4 & 2 & 1 & 6 & 2 & 4 & 3 & 3 & & 2 & 3 & 4 & 1 & 1 & 2 & 0 & 1 & \\
\hline Bank-oriented & 4 & 4 & 6 & 1 & 1 & 0 & 1 & 4 & 4 & 2 & 1 & 4 & 1 & 2 & 2 & 1 & & 1 & 0 & 3 & 1 & 1 & 1 & 0 & 1 & \\
\hline Insurance-oriented & $\underline{3}$ & $\underline{2}$ & 0 & 1 & \begin{tabular}{|l|}
1 \\
\end{tabular} & 1 & 1 & $\underline{3}$ & 0 & 0 & 0 & $\underline{2}$ & 1 & 2 & 1 & 2 & & 1 & 3 & 1 & \begin{tabular}{|l|l|}
0 & \\
\end{tabular} & 0 & 1 & \begin{tabular}{|l|}
0 \\
\end{tabular} & 0 & \\
\hline
\end{tabular}

Note: * - bank-oriented conglomerates; ** - insurance-oriented conglomerates; ““_" No corresponding component of conglomerate; number from 1 to 6 - rank indicator;

BANK 1 - assets of the bank; BANK 2 - volume of bank commitments; BANK 3 - the amount of liabilities; BANK 4 - equity; BANK 5 - the financial results; BANK 6 - ROE (return on equity); BANK 7 - ROA (return on assets); BANK 8 - ME (multiplier of equity); BANK 9 - equity/liabilities (ratio of equity to total liabilities ); BANK 10 - equity adequacy; BANK 11 - coefficient of activity in involvement of borrowed funds; BANK 12 - financial leverage;

INS 1 - assets; INS 2 - equity; INS 3 - liabilities; INS4 - gross premiums; INS 5 - gross payments; INS 6 - insurance reserves; INS 7 - coefficient of total debt; INS8 - coefficient of current liquidity; INS9 - coefficient of adequacy of reserves; INS 10 - coefficient of business activity; INS11 - coefficient of debt burden; INS12 - coefficient of losses.

The presence-absence of representatives of the investment sector (INV) as a part of a financial conglomerate affects binary variables ( 1 or 0$)$.

Analysis of Table 2 allows to draw conclusions: 
1. The main characteristics of bank-oriented and insurance-oriented conglomerates are: BANK 1 - assets; BANK 2 - liabilities; BANK 8 - EM; BANK 12 - financial leverage (evaluation of banks).

2. Specific indicators of bank-oriented conglomerates are indicators such as BANK 3 - liability; BANK 9 - equity / liabilities (evaluation of the bank) and INS 7 - coefficient of total debt (evaluation of insurance companies).

3. Defining terms of insurance-oriented conglomerates are INS 2 - equity; INS 4 - gross premiums; INS 6 - insurance reserves (characteristics of the insurance company).

Stage 2. Structural analysis of the relationship between the elements of conglomerates. At this stage, the system of structural equations (equations system paired regression relationship between the levels of development of the banking and investment conglomerate components and their performance characteristics) is constructed. For this latent variables are introduced: BANK - level synthesis of performance evaluation in terms of the functioning of the bank group "Privat", INV - level performance characteristics of the investment market. Since this conglomerate is bank-oriented, so it can be considered as an endogenous variable exactly generalizing the level of performance evaluation of the functioning of the bank. The results of the structural analysis arre presented in Figure 8.

\begin{tabular}{|l|r|r|r|r|r|}
\hline & \multicolumn{4}{|c|}{ Model Estimates (Spreadsheet1.sta) } \\
\cline { 2 - 6 } & $\begin{array}{c}\text { Parameter } \\
\text { Estimate }\end{array}$ & $\begin{array}{c}\text { Standard } \\
\text { Error }\end{array}$ & $\begin{array}{c}\text { T } \\
\text { Statistic }\end{array}$ & $\begin{array}{c}\text { Prob. } \\
\text { Level }\end{array}$ \\
\hline (BANK)-1->[BANK8] & 0,746 & 0,215 & 3,464 & 0,001 \\
\hline (BANK)-2->[BANK9] & $-0,008$ & 0,002 & $-3,446$ & 0,001 \\
\hline (BANK)-3->[BANK12] & 0,744 & 0,215 & 3,464 & 0,001 \\
\hline (DELTA1)-->[BANK8] & & & & \\
\hline (DELTA2)-->[BANK9] & & & & \\
\hline (DELTA3)-->[BANK12] & & & & \\
\hline (DELTA1)-4-(DELTA1) & 0,000 & 0,000 & 1,732 & 0,083 \\
\hline (DELTA2)-5-(DELTA2) & 0,000 & 0,000 & 1,732 & 0,083 \\
\hline (DELTA3)-6-(DELTA3) & 0,000 & 0,000 & & \\
\hline (INV)-->[INV1] & & & & \\
\hline (EPSILON1)-->[INV1] & & & & \\
\hline (EPSILON1)-7-(EPSILON1) & 0,500 & 0,000 & & \\
\hline (ZETA1)-->(INV) & & & & \\
\hline (ZETA1)-8-(ZETA1) & $-0,000$ & 0,000 & & \\
\hline (BANK)-9->(INV) & $-0,104$ & 0,290 & $-0,357$ & 0,721 \\
\hline
\end{tabular}

Figure 8. Structural analysis of the relationship between the elements in group "Privat"

Based on the parameters used in Figure 8, authors write econometric models of the relationship between elements of group "Privat":

$$
\left\{\begin{array}{l}
B A N K 8=0.746 \cdot B A N K \\
B A N K 9=-0,008 \cdot B A N K \\
B A N K 12=0.744 \cdot B A N K \\
I N V 1=I N V+0.500 \\
I N V=-0,104 \cdot B A N K
\end{array}\right.
$$

The analysis of the equation (1) suggests: indicators BANK 8 - EM and BANK 12 - financial leverage have a positive impact on important summary measure evaluating the level of the bank as part of a conglomerate unlike index BANK 9 - equity / liabilities, whose influence is negative. In addition, the investment market relationship between the level of development of the market and its assessment index also has a positive sign that its growth is accompanied by an increase in effective signs. Turning to the analysis of the relationship between the bank and the investment market bank-oriented conglomerate "Privat" considered as items, we note that the relationship is inverse, that increased levels of the banking component of $1 \%$ is accompanied by a reduction of investment at $0.104 \%$ and vice versa.

The adequacy of the reduced system confirmed by criteria of Stinger-Lind, Mcdonald, gamma- index, actual values are displayed on Figure 9. 


\begin{tabular}{|l|r|r|r|}
\hline \multirow{2}{*}{} & \multicolumn{3}{|c|}{ Noncentrality Fit Indices (Spreadsheet1.s) } \\
\cline { 2 - 4 } & $\begin{array}{c}\text { Lower 90\% } \\
\text { Conf. Bound }\end{array}$ & $\begin{array}{c}\text { Point } \\
\text { Estimate }\end{array}$ & $\begin{array}{c}\text { Upper 90\% } \\
\text { Conf. Bound }\end{array}$ \\
\hline Population Noncentrality Parameter & 0,000 & 0,000 & 1,298 \\
\hline Steiger-Lind RMSEA Index & 0,000 & 0,000 & 0,806 \\
\hline McDonald Noncentrality Index & 0,523 & 1,000 & 1,000 \\
\hline Population Gamma Index & 0,606 & 1,000 & 1,000 \\
\hline Adjusted Population Gamma Index & $-0,968$ & 1,000 & 1,000 \\
\hline
\end{tabular}

Figure 9. Indices to check the adequacy of the centrality of structural equations conglomerate "Privat"

Thus, based on a detailed analysis of the results of structural analysis a generalization of quantitative estimates and trends was conducted. Assessment of conglomerates is presented in Table 2.

Table 2. Assessment of the relationship of financial conglomerates and financial market development by using structural analysis

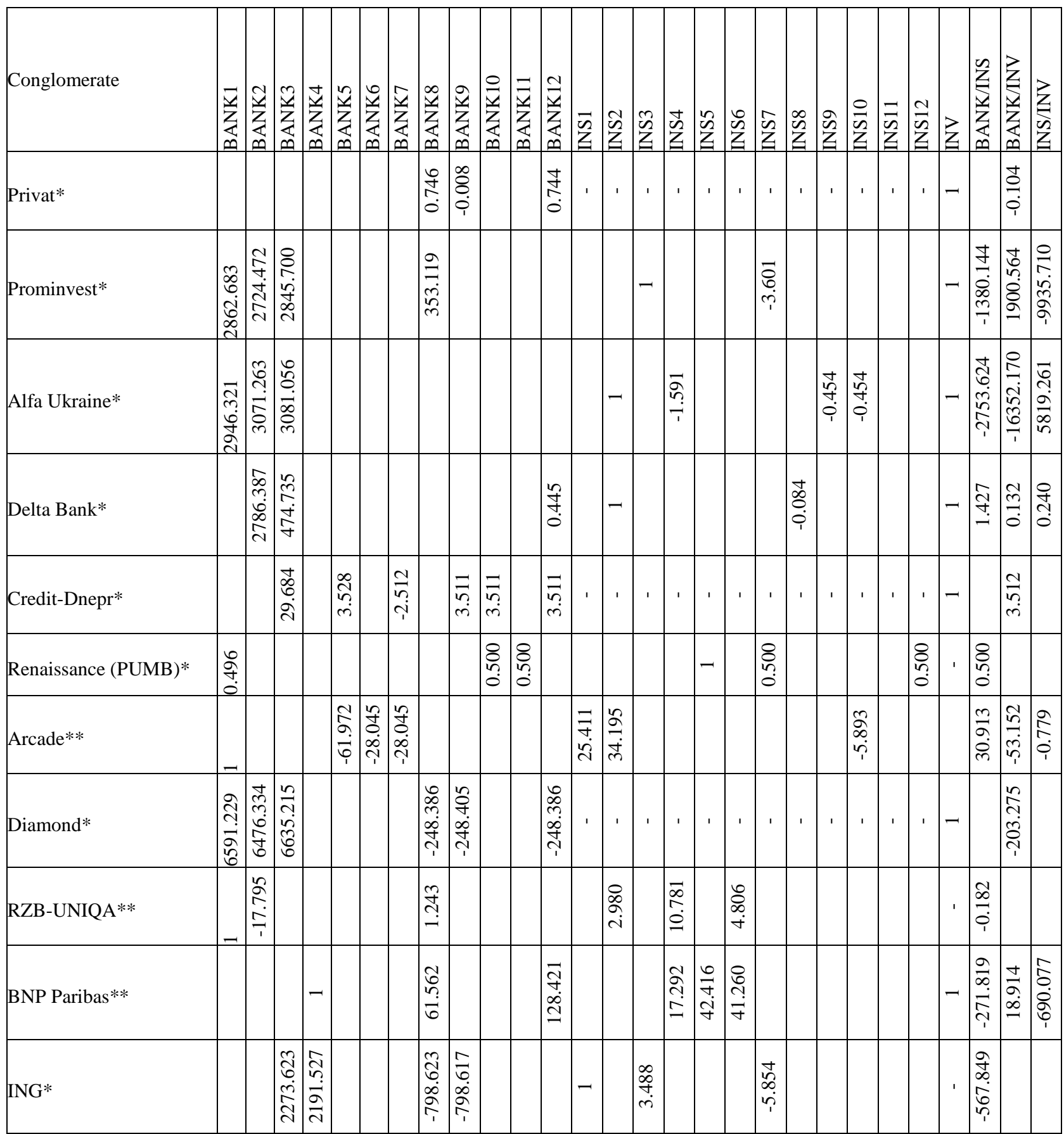




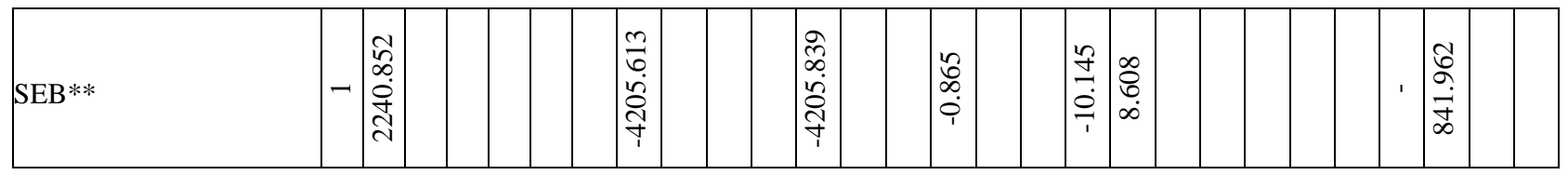

Note: $*$ - bank-oriented conglomerates; $* *$ - insurance-oriented conglomerates.

Stage 3. Evaluation of relevant factors influencing the unstable conglomerates. At this stage, there is a need to build a matrix-reflector, based on which we can determine whether exercise decisive influence on the stability of the conglomerate relevant performance characteristics forms its elements; which is a quantification of the said impact. The closer the matrix elements reflecting zero, the less sensitive resistance conglomerate is considered when a certain indicator of its theoretical limit possible limits.

\begin{tabular}{|l|r|r|r|r|}
\hline \multirow{2}{*}{} & \multicolumn{3}{|c|}{ Reflector Matrix (Spreadsheet1.sta) } \\
\cline { 2 - 5 } & \multicolumn{1}{|c|}{ BANK8 } & BANK9 & BANK12 & \multicolumn{1}{|c|}{ INV1 } \\
\hline BANK8 & 0,000 & $-0,018$ & 0,000 & 5,914 \\
\hline BANK9 & $-1,821$ & 0,000 & $-0,000$ & $-177,223$ \\
\hline BANK12 & $-0,021$ & 0,018 & 0,000 & $-7,834$ \\
\hline INV1 & 0,000 & $-0,000$ & $-0,000$ & 0,736 \\
\hline
\end{tabular}

Figure 10. The matrix reflecting the evaluation of relevant factors influencing the stability of the conglomerate "Private"

Thus, based on a detailed analysis of the results of the method of principal components, summarizing the most influential factors of considered elements Was held an assessment of system conglomerates, is offered to bring in tabular form (Table 3).

Table 3. Results of systematization in the evaluation of relevant factors influencing on the instability of conglomerates

\begin{tabular}{|c|c|c|c|c|c|c|c|c|c|c|c|c|c|c|c|c|c|c|c|c|c|c|c|c|c|}
\hline \multirow{2}{*}{ 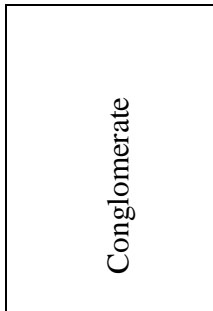 } & \multicolumn{12}{|c|}{ Bank (BANK) } & \multicolumn{12}{|c|}{ Insurance company (INS) } & \multirow{2}{*}{\begin{tabular}{|c}
$\begin{array}{c}\text { Investment } \\
\text { market } \\
\text { (INV) }\end{array}$ \\
Z
\end{tabular}} \\
\hline & $\underset{n}{\vec{z}}$ & $\frac{\tilde{z}}{z}$ & $\underset{n}{Z}$ & 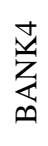 & 尝 & \begin{tabular}{l}
0 \\
$u$ \\
$z$ \\
\hdashline \\
$\infty$
\end{tabular} \mid & 点 & 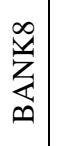 & $\frac{2}{z}$ & 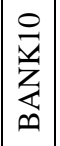 & $\begin{array}{l}\overline{\vec{v}} \\
z \\
z \\
\underline{n}\end{array}$ & 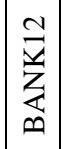 & $\bar{\Sigma}$ & $\begin{array}{l}\tilde{v} \\
\tilde{n} \\
Z\end{array}$ & $\begin{array}{l}n \\
\tilde{n} \\
Z\end{array}$ & $\begin{array}{l}\text { 艺 } \\
\text { Z }\end{array}$ & $\begin{array}{l}n \\
n \\
z\end{array}$ & $\begin{array}{l}0 \\
\mathscr{2} \\
\text { Ż }\end{array}$ & $\begin{array}{l}\hat{n} \\
\tilde{Z}\end{array}$ & $\begin{array}{l}\infty \\
n \\
\text { Z }\end{array}$ & $\begin{array}{l}\hat{2} \\
\text { Z }\end{array}$ & $\begin{array}{l}0 \\
\text { 号 } \\
\text { Z }\end{array}$ & $\begin{array}{l}\bar{Z} \\
\bar{\Omega} \\
\text { Z }\end{array}$ & $\begin{array}{l}\sim \\
\sim \\
\text { Z } \\
Z\end{array}$ & \\
\hline Privat* & & & & & & & & & + & & & & & & & & & & & & & & & & \\
\hline Prominvest* & + & + & + & & & & & + & & & & & & & + & & & & + & & & & & & + \\
\hline Alfa Ukraine* & + & + & + & & & & & & & & & & & + & & + & & & & & + & + & & & + \\
\hline Delta Bank* & & + & + & & & & & & & & & + & & + & & & & & & + & & & & & + \\
\hline Credit-Dnepr* & & & + & & + & & + & & + & + & & + & & & & & & & & & & & & & + \\
\hline $\begin{array}{l}\text { Renaissance } \\
\text { (PUMB)* }\end{array}$ & + & & & & & & & & & + & + & & & & & & + & & + & & & & & + & \\
\hline Arcade $^{* *}$ & + & & & & + & + & + & & & & & & + & + & & & & & & & & + & & & + \\
\hline Diamond* & + & + & + & & & & & + & + & & & + & & & & & & & & & & & & & + \\
\hline RZB-UNIQA** & + & + & & & & & & + & & & & & & + & & + & & + & & & & & & & \\
\hline BNP Paribas** & & & & + & & & & + & & & & + & & & & + & + & + & & & & & & & + \\
\hline $\mathrm{ING}^{*}$ & & & + & + & & & & + & + & & & & + & & + & & & & + & & & & & & \\
\hline SEB ** & + & + & & & & & & + & & & & + & & & + & & & + & + & & & & & & \\
\hline
\end{tabular}

Note: $*$ - bank-oriented conglomerates; $* *$ - insurance-oriented conglomerates.

Stage 4. Calculation of indicators of financial instability conglomerates. It is proposed as this indicator module adopt determinant of the matrix reflecting defined in the previous step in the context of each of the conglomerates considered using MOPRED in MS Excel. adjusted by a factor that allows you to bring the resulting value to range from zero to one and submit the resulting value in percentage terms. Results received for illustrative calculations will result in tabular form. 
Table 4. Assessment of the relationship of financial conglomerates and financial market development by using structural analysis

\begin{tabular}{|l|c|}
\hline \multicolumn{1}{|c|}{ Conglomerate } & Evaluation of instability \% \\
\hline Privat* & 64.20 \\
\hline Prominvest* & 51.84 \\
\hline Alfa Ukraine* & 68.58 \\
\hline Delta Bank* & 15.36 \\
\hline Credit-Dnepr* & 45.53 \\
\hline Renaissance (PUMB)* & 91.56 \\
\hline Arcade** & 56.31 \\
\hline Diamond* & 44.20 \\
\hline RZB-UNIQA** & 35.68 \\
\hline BNP Paribas** & 10.88 \\
\hline ING* & 81.63 \\
\hline SEB** & 43.58 \\
\hline
\end{tabular}

Note: $*$ - bank-oriented conglomerates; $* *$ - insurance-oriented conglomerates.

\section{Conclusion}

The analysis led to the conclusion that insurance-oriented FC presented in the financial market of Ukraine are more stable. Thus, the volatility index ranges from $10.88 \%$ in FC "BNP Paribas" to $56.31 \%$ in FC "Arcade". This is because financial intermediaries such integrated bancassurance are mostly foreign companies and have a more developed system of risk management based on the principle of detection of instability inside the structure in the early stages and significant financial support from the parent company. Index volatility of bank-oriented FC is in the range of $44.2 \%$ (FC "Diamond") to $91.56 \%$ in FC "Renaissance" (FUIB). FC of allfinanz type overcome the crisis, experiencing significant losses. The group includes system-FC (Group "Privat", 64.2\% "Prominvest" $51.84 \%$, and "Alpha-Ukraine" $68.58 \%$ ). Given the state of the banking system that operates in difficult macroeconomic and political conditions, such results are quite reasonable.

\section{References}

1. Aig / American International Group, Inc. / Corporate Information Retrieved from: www.aigcorporate.com

2. Allianz Insurance, Asset Management and Banking worldwide: Retrieved from: http://www.allianz.com

3. Assessing the Sustainable Competitiveness of Nations (2012). The global Competitiveness Report 20122013. World Economic Forum, Geneva, 2012, 545 p. Retrieved from: http://www3.weforum.org/docs/ WEF_GlobalCompetitivenessReport_2012-13.pdf

4. Banque BNP Paribas / La banque d'un monde qui change: Retrieved from: http://www.bnpparibas.com

5. European Parliament and Council Directive 2002/87/EC of 16 December 2002 on the supplementary supervision of credit institutions, insurance undertakings and investment firms in a financial conglomerate and amending Council Directives 73/239/EEC, 79/267/EEC, 92/49/EEC, 92/96/EEC, 93/6/EEC, 93/22/EEC , 98/78/EC and 2000/12/EC Retrived from: http://europa.eu/scadplus/leg/en/lvb/124038c.htm

6. Kozyriev V., Kozmenko S. (2015). The research and development of financial conglomerates based on the estimate of integration of components of financial market. Insurance Markets and Companies: Analyses and Actuarial Computations. International Research Journal. 6 (3), 34-44.

7. Johnson J., Madura J. (2000). Valuing the potential transformation of banks into financial conglomerates: evidence from a Citigroup merger. The Financial Review. 35, 17-36.

8. Global Risks 2013. Eighth Edition An initiative of the Risk Response Network. [Електронний ресурс] / World Economic Forum. Retrieved from: http://riskreport.weforum.org/

9. Minsky H. The Financial Instability Hypothesis (1992). Retrieved from: http://www.levyinstitute.org/pubs/wp74.pdf.

10. Violaris Y. Bancassurance in practice (2001). Retrieved from: http://www.marclife.com/research/pdf/banc.pdf.

11. Insurance Sector: a sector with possibilities (2009). Retrieved from: www.madridfinancialcentre.org/.../ficha-xi-seguros-ingles-final-julio-09.doc. 